\begin{tabular}{|c|c|c|}
\hline $\begin{array}{l}\text { EXCELLENT } \\
\text { PUBLISHERS }\end{array}$ & 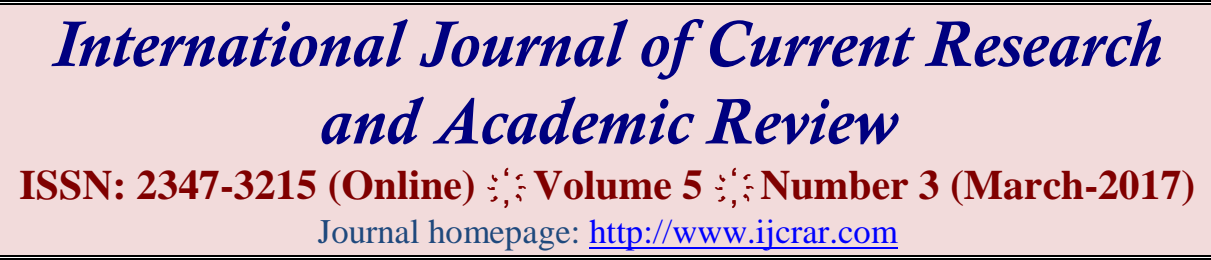 & 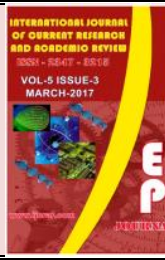 \\
\hline
\end{tabular}

doi: $\underline{\text { https://doi.org/10.20546/ijcrar.2017.503.012 }}$

\title{
General Aspects of Pteridophyta - A Review
}

\author{
Teena Agrawal*, Priyanka Danai and Monika Yadav \\ Department of Bioscience and Biotechnology, Banasthali Vidyapith, Rajasthan, India \\ *Corresponding author
}

\begin{abstract}
Pteridophyta is a phylum of plants which is commonly known as ferns. About more than 12,000 different species of ferns are distributed worldwide. They are distinguished from flowering plants by not producing seeds \& fruit. The members of Pteridophyta reproduce through spores. Ferns were some of the Earth's first land plants. They are vascular and have true leaves. In evolutionary history, the advent of vascular plants changed the way the world looked. Prior to the spread of vascular plants, the land had only plants that were no more than a few centimeters tall; the origin of the vascular system made it possible for plants to be much taller. As it became possible for plants to grow taller, it also became necessary - otherwise, they would get shaded by their taller neighbors. With the advent of vascular plants, the competition for light became intense, and forests started to cover the earth. (A forest is simply a crowd of plants competing for light). The earliest forests were composed of vascular non-seed plant, though modern forests are dominant by seed plant.
\end{abstract}

\section{Article Info}

Accepted: 28 February 2017

Available Online: 10 March 2017

\section{Keywords}

Pteridophyta, Ferns,

Vascular plants,

Evolutionary history.

\section{Introduction}

The division Pteridophyta includes a group of primitive vascular plants, commonly called pteridophytes. The adult plant body in these plants is a sporophyte. It shows differentiation into true roots, stem and leaves. The stem is mostly herbaceous. Leaves may be smaller or larger. Vascular tissues are present in all the vegetative parts of the plant body. Example- Selaginella, Pteris, Adiantum, Dryopteris (Hoshizaki and Robbin, 2001).

Wolf et al., (2010) examine for the first time the structure of the plastome across fern phylogeny. They used a PCR-based strategy to map and partially sequence plastomes. They found that a pair of partially overlapping inversions in the region of the inverted repeat occurred in the common ancestor of most ferns.
However, the ancestral (seed plant) structure is still found in early diverging branches leading to the osmundoid and filmy fern lineages (Duffy, 2010).

Chase et al., (2014) concluded that a classification is presently based on our current understanding of relationships of fern and lycopodclades. Major changes in their understanding of these families are highlighted, illustrating issues of classification in relation to convergent evolution and false homologies. A new classification in which Aspleniaceae, Cyatheaceae, Polypodiaceae and Schizaeaceae are expanded in comparison with the most recent classifications is presented, which is a modification of those proposed by (Smith et al., 2008) and (Christenhusz et al., 2011). These classifications are now finding a wider acceptance and use, and even though a few amendments are made 
based on recently published results from molecular analyses, they have aimed for a stable family and generic classification of ferns (Christenhusz, 2014).

(Chandra et al., 2012) also noted that Lygodium flexuosum (Linn) Sw. is a fern found nearly throughout India up to an elevation of 1500 meter. It belongs to the family Lygodiaceae and widely used in treating various ailments like jaundice, dysmenorrhea, wound healing and eczema. It is the rich source of alkaloids, flavonoids, saponins and coumarins. The main constitute of the plant is lygodinolide which is mainly used in wound healing (Ghosh et al., 2012).

\section{Reproduction}

Reproduction involves production of spores inside special structures called sporangia which occur on the ventral surface of fertile leaves called sporophylls. Sporangia may sometimes be found in groups called sori.

The plants may be homosporous - producing only one type of spore or heterosporous - producing two different types of spores; smaller microspores and larger megaspores.

The spores germinate to produce a haploid gametophyte, called prothallus. The homosporous pteridophytes produce bisexual gametophytes while heterosporous pteridophytes produce unisexual gametophytes.

In gametophytes, reproduction is of oogamous type. The male sex organs are called antheridia and female sex organs are called archegonia. Antheridia produce antherozoids and archegonia enclose the egg cell. Fertilisation requires water. The diploid zygote is retained in the archegonial venter where it develops into an embryo. Subsequently it becomes a young sporophyte and grows into an independent adult plant. Thus the life cycle includes an alternation of diploid sporophytic generation with a haploid gametophytic generation. Sporophytic generation is dominant in the life cycle (Stace and Clive, 2010).

\section{Classification of Pteridophyta}

Pteridophytes have been divided into four sub- division these are-

Psilophyta

Lycopodophyta (club mosses)

Sphenophyta (horse tail)
Filicinophyta (ferns)

\section{Classification of Pteridophyta (according to Renchang Qing's classification system)}

\section{Psilophytina}

Spore has only rhizoid, leaf is microphyll, stem dichotomous branches many times, sporangium is born close to the top of sporophylls, homospory, monoecism, spermatozoid in spiral shape, has many flagellums.

\section{Lycopshytina}

Spore has differentiation of root stem and leaf; leaf is microphyll: only one midrib, no folial gap; sporangium develops to strobile and sporophylls spike; homospory or heterospory (Murdock and Andrew, 2014).

\section{Isoephytina}

Born beside water or at the bottom of water, leaf is thin and long like chive, grow thickly on the short branch's stem, heterospory, spermatozoid has many flagellums.

\section{Sphenophytina}

Stem has apparent node and internodes, leaf is small scale shaped, sporangium is born on the top of branch, petite, homospory, and spermatozoid has many flagellums.

\section{Filicophytina}

Separate criteria: according to the location, morphosis and developmental way and sequence of sporangium. We separate Filicophytina into three classes:

Eusporangiopsida: Sporangium has thick wall, is composed of several layers of cells. Sporangium origin from a group of cells: Ophioglossales and Angiopteriales (Munster et al., 2002).

Protoleptosporangiopsida: The wall of sporangium is composed of one layer of cells. The sporangium origin from one or a group of cells, such as Osmunda vachellii Hook.

Leptosporangiopsida: The sporangium is composed of one layer of cells. It originates from one cell. 


\section{Represented Plants}

Marsilea- Hydric, leaf has long stipe, four leaflets are born on the petiolar top. The petioleis soft, leaf blade can float with water. When breeding, it produces ambisexual sporocarp, endogen ate sori and micro or macrosporangia. Macro and microsporangia are located on the colloid. Sporocarp become mature, the colloid expansion after sop and then stretch out of sporocarp, at the same time also bring the sporangium out of the wall of fruit.

Azolla imbricate- It is also called Azolla, water fern. Leaf is arranged like watt on the stem, it has no stipe. Split deeply into upper and down valve. The upper valve floats on the water, operate photosynthesis. Sporocarp is heteromorphosis which can separate into macrospore and microspore (Benjamin, 2007).

Ferns are the most diverse group of vascular plant after seed plant. They are the second largest group of vascular plant, with more than 10,000 species that reproduce via spore and have neither seed nor flower. They have differed from mosses by being vascular (i.e. having water-conducting vessel) (Jim, 2013). Fern are green flowerless plants with divided leaves that tend to grow in damp, shady areas. The developing leaves of most ferns uncoil from a koru (Nature of Science, 2010).

\section{Structure of Ferns}

Ferns have 3 major parts - the rhizome, the fronds and the reproductive structures called sporangia. The characteristics of each of these 3 parts of the fern plant are used for classification and identification.

The rhizome is the stem of the fern plant. It comes in 3 basic forms:

An erect rhizome, which is a solid mass that give rise to a tuft of fronds. This type of rhizome on a king fern or a crown fern.

A laterally growing rhizome that creeps along or under the ground. It may even climb up a tree. Hound's tongue and thread ferns are examples of a fern with a creeping rhizome.

A vertical rhizome. This can grow into a short or a tall trunk. The trunk of the ponga (silver fern) is a vertical rhizome (Link, 2015).

The fronds are the leaves of the fern. There is usually a stalk (the stipe) with a flat blade (the lamina), often divided into segments. The frond may be simple and undivided or it may be divided into a number of divisions (called pinnae). New fronds are produced from the rhizome. They are tightly coiled into a spiral (called a fiddlehead or koru), and these slowly uncoil as they mature. Fronds have a dual function. They are there for photosynthesis but they are also there for reproduction.

The spore grows inside casings called sporangia. These are found on the underside of fronds. Not every frond has sporangia underneath it. Fronds that have sporangia are called fertile fronds. In the vast majority of ferns, the sporangia are found in clusters (called sori). These are the brown, black or orange patches that you see on the underside of fronds. When the sporangia break open, they release the spore (Attwood, 2010).

\section{Reproductive structure of ferns}

Ferns are unique amongst land plants in that they have 2 separate living structures in their reproductive cycle -the sporophyte and the gametophyte. The leafy fern plants in the bush that produce spores are sporophytes. When the spores are released by the sporangia, if they land in a suitable environment, they can grow into a tiny plant-the gametophyte (Jim, 2013). This inconspicuous, shortlived plant has 2 type of reproductive organ- the antheridia (male) and the archegonia (female). In suitable moist conditions, fertilization occur either on the same gametophyte. Fertilization gives rise to a new sporophyte. No other land plant has these 2 separate independent living stages. This is a unique characteristic of ferns (Vasco et al., 2013).

\section{Evolution of Ferns}

Fern are an ancient group of plants. Fossil record of fern, consider that land plant emerged from the water around 475 million year ago. By about 400 million year ago, vascular plant has seperate from the non-vascular plant (Korall et al., 2007). By about 350 million year ago, some of the major families of ferns are seen in the fossil record. Fern first appear in the fossil record in the earlyCarboniferous period. By the Triassic period, the first evidence of ferns related to several modern families appeared the "great fern radiation" occurred in the lateCretaceous, when many modern families of fern first appeared. The oldest fossils of land plants visible with the naked eye come from Ireland and date from the Middle Silurian (425 million years). 
Table.1 Classification

\begin{tabular}{|c|c|c|}
\hline Lycopodophyta & Sphenophyta & Filicinophyta \\
\hline $\begin{array}{c}\text { Leaves relatively small (microphyllous), spirally } \\
\text { arranged around the stem }\end{array}$ & $\begin{array}{c}\text { Leaves relatively small, arranged } \\
\text { in whorls around the stem }\end{array}$ & $\begin{array}{c}\text { Leaves relatively large (macrophyllous) and are called } \\
\text { fronds, spirally arranged around the stem }\end{array}$ \\
\hline $\begin{array}{c}\text { Includes both homosporous and heterosporous } \\
\text { forms }\end{array}$ & $\begin{array}{c}\text { Includes only homosporous } \\
\text { forms }\end{array}$ & Sporangia usually in sori \\
\hline $\begin{array}{c}\text { Sporangia mostly found in clusters (strobil or } \\
\text { cones) }\end{array}$ & $\begin{array}{c}\text { Sporangia in strobili, on } \\
\text { sporangiophores }\end{array}$ & Example Dryoptera 'pteridium \\
\hline $\begin{array}{c}\text { Examples selegina(Homosporous)Lycoporous } \\
\text { (heterosporous) }\end{array}$ & $\begin{array}{c}\text { Examples Equisetum (Only } \\
\text { surviving genus) }\end{array}$ \\
\hline
\end{tabular}

Fig.1 Life cycle of Pteridophyta (http://www.tutorvista.com)

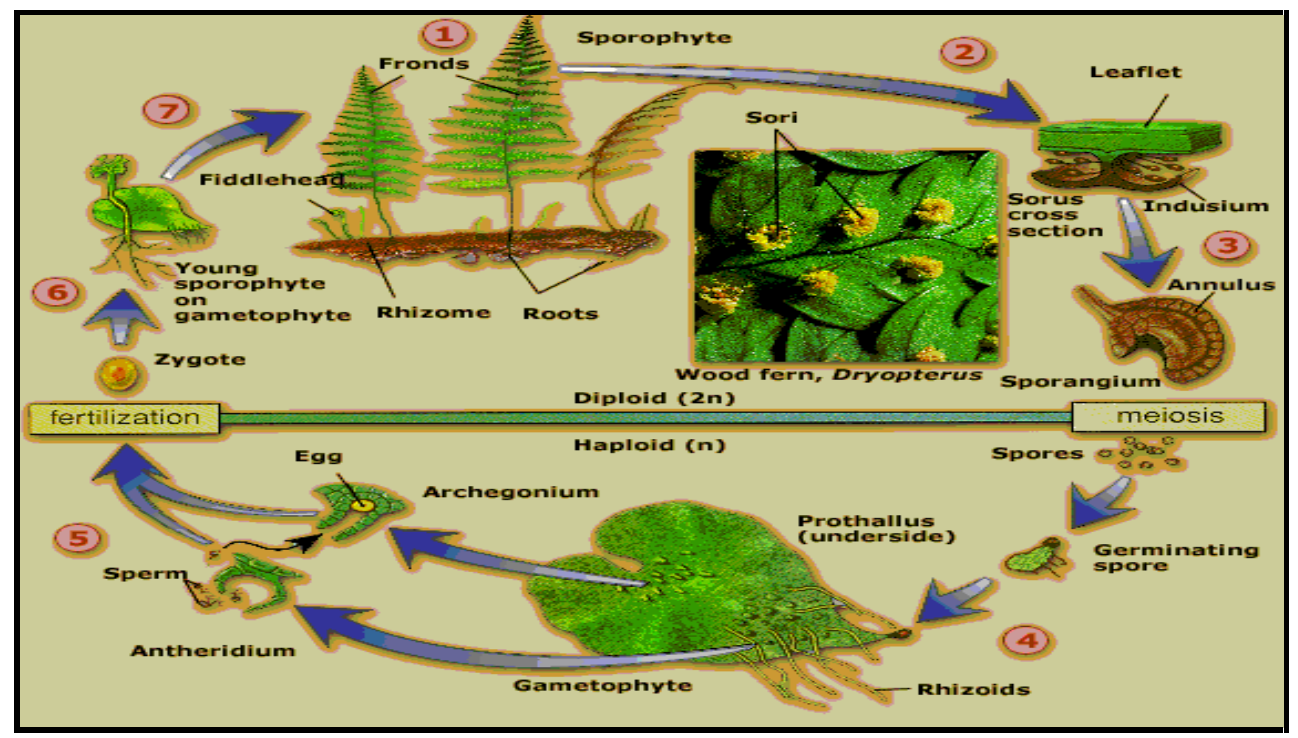

Fig.2 The Fern Family Tree (http://www.ferns.rogergolding.co.uk/index.html)

\begin{tabular}{|c|c|c|}
\hline PTERIDOPHYTA - & $\begin{array}{c}\text { Class } \\
\text { —PSILOTOPSIDA } \\
\text {-EQUISETOPSIDA- } \\
\text {-MARATTIOPSIDA- } \\
\text {-POLYPODIOPSIDA- }\end{array}$ & $\begin{array}{l}\text { Order } \\
\text {-PSILOTALES } \\
\text { OPHIOGLOSSALES } \\
\text { —EQUISETALES } \\
\text { —MARATTIALES } \\
\text {-OSMUNDALES } \\
\text {-HYMENOPHYLLALES } \\
\text { GLEICHENIALES } \\
\text {-SCHIZAEALES } \\
\text {-SALVINIALES } \\
\text {-CYATHEALES } \\
\text {-POLYPODIALES }\end{array}$ \\
\hline
\end{tabular}


Fig.3 Method of Fern in-situ culture (http://www.ferns.rogergolding.co.uk/index.html)

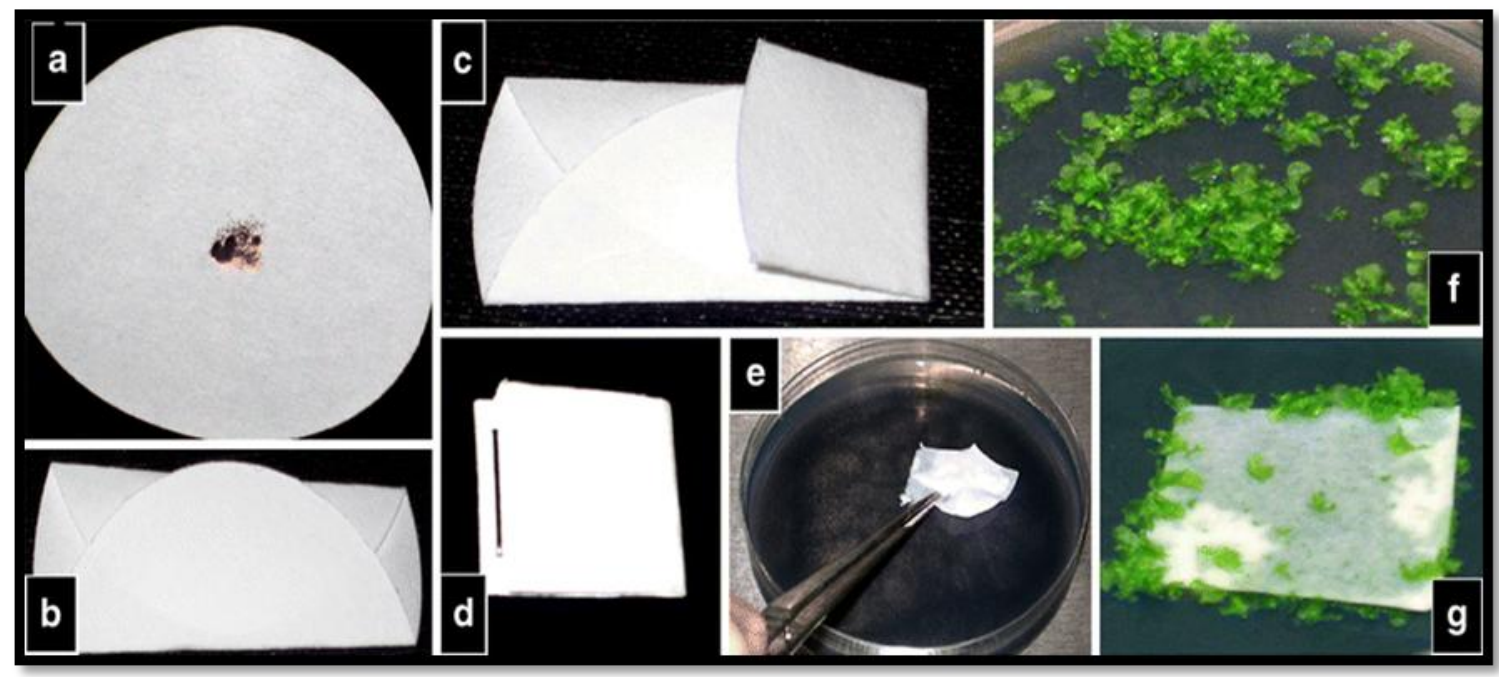

These are very small plants up to a couple a centimeters high, called Cooksonia. Near to the Scottish village of Rhynia a silicified flora has been found dating from the Lower Devonian (408 million years). During the Devonian (410 - 355 million years) a rather strangelooking flora evolved from the Rhyniophyta which must have included the ancestors of the ferns (Taylor et al., 2009).

\section{Classification of Ferns}

Ferns have traditionally been grouped in the Class Filices, but modern classifications assign them their own division in the plant kingdom, called Pteridophyta, also known as Filicophyta. The group is also referred to as Polypodiophyta, (Polypodiopsida when treated as a subdivision of tracheophyta (vascular plants), although Polypodiopsida sometimes refers to only the leptosporangiate fern) (Marteen et al., 2011). Leptosporangiate fern contain 7 orders. Eusporangiate fern refer to four classes: Psilotopsida, Equisetopsida and Marattiopsida. Eusporangiate ferns are vascular spore plants, whose sporangia arise from several epidermal cells and not from a single cell as in leptosporangiate ferns. Typically these ferns have reduced root systems and sporangia that produce large amounts of spores (Bank, 1992).

\section{Distribution of fern}

Ferns are distributed across all over world. For example: America, Europe and Asia etc. In India different type of species are found. Central India includes 10 species of
Fern allies and 68 species of Ferns (Dudani et al., 2014). Tamia, Pachmarhi, Patalkot and AchanakmarAmarkantak Biosphere reserve are the hot spot for Ferns (Wolf et al., 2001). Eastern Himalayan Region: Sikkim, Darjeeling district of West Bengal and 7 states of NorthEast (Arunachal Pradesh, Assam, Nagaland, Manipur, Meghalaya, Mizoram and Tripura) are included as important areas for different ferns species (Vahhemessen, 2013).

\section{Conservation of fern}

Conservation of fern are done by many method-

Fern species are growing in greenhouse to maintain their biodiversity

Transplanting of tree fern from these are to safe region (mainly these are apply in Mexico) (Eleuterio and Salicrup, 2009)

Through fern spore storage in conventional freezers.

In-situ and Ex-situ fern culture these are conserved. The homestead Muslim graveyards of rural areas under Khardah Police station have played a most significant role in, in-situ conservation of fern in that locality (Chakarborty et al., 2012).

\section{Significance of fern}

Ferns are not as important economically as seed plants but have considerable importance in some societies. 
Some ferns are used for food, including the fiddleheads of bracken, ostrich fern. Ferns are generally not known to be poisonous to humans (Pelton and Robert, 2012).

Ferns of the genus Azolla are very small, floating plants that do not resemble ferns. Called mosquito fern, they are used as a biological fertilizer in the rice paddies of Southeast Asia, taking advantage of their ability to fix nitrogen from the air into compounds that can then be used by other plants (Vu, 2016).

The hardy fern has a root system that branches out and adds moisture to the soil, which helps prevent soil erosion and aids stabilization.

Many ferns are grown in horticulture as landscape plants

Fern are used for timber e.g. Tree fern.

Maidenhair ferns contain flavanoids. Ancient healers would use tea from the maidenhair fern to cure coughs and nasal congestion.

It contains phosphorous, a mineral needed for healthy bones.

Dryopteris cochleata is used in mental disorder in India (Srivastava, 2007). Pteris vittata (brake fern) used to absorb arsenic from the soil (Benniamin, 2009).

\section{References}

Bank, H.P. 1992. The classification of early vascular plants. Geophytol., 22: 49:63.

Benjamin, A. and Manickam, V.S. 2007. Medicinal pteridophytes from the Western Ghats. Indian J. Trad. Knowl., 6: 611-618.

Braggins, John, E. and Mark, F. 2004. Tree Ferns. Timber Press, Inc.94. ISBN 0-88192-630-2.

Chakraborti, A., Chakarborti, K. and Bandyobadhyay, M. 2012. Conservation of Ferns in the Muslim graveyards of Khardan rural areas.

Chandra, P., Sachan, N., Yadav, E., Mani, M. and Ghosh, A.K. 2012 A review on therapeutic potential of Lygodium flexuosum Linn. 6(12): 107- 114.

Chase, M.W. and Christenhusz, M.J. 2014. Trends and Concepts in Fern Classification, 113(4): 571-94.
Dudani, S.N., Mahesh, M.K., Subash, C.M.D. and Ramachandra, T.V. 2014. Pteridophyte diversity in wet evergreen forests of Sakleshpur in Central Western Ghat, 3(1): 28-39.

Eleuterio, A.A. and Salicrup, D.P. 2009. Transplanting Tree Fern to Promote fern Conservation in Mexico. 99(4): 279291.

Hoshizaki, B.J. and Robbin, C.M. 2001. Fern grower's manual, 2: 517.

http://www.natureloveyou.sg/Dipteris\%20conjugata/Main.htm 1

http://www.tutorvista.com/content/biology/biologyiii/kingdoms-living-world/pteridophytes.php

Jim, M. 2013. Rediscover Fern.

Korall, P., Conant, D.S., Metzgar, J.S., Schneider,h. and Pryer, K.M. 2007. A Molecular phylogeny of scaly tree ferns (Cyatheaceae). American J. Bot., 94(5): 873-886.

Link, C. 2015. What is Fern? Nature Hills.com

Maarteen, J.M., Husz, C. and Chase, M.W. 2014. Trends and concept in Fern classification, 571-594.

Munster, T., Faigl, W., Saedler, H. and Theissen, G. 2002. Evolutionary aspects of MADS-box genes in the eusporangiate fern Ophioglossum. 4(4): 474-483.

Murdock and Andrew, G. 2008. A taxonomic revision of the eusporangiate fern family Marattiaceae, with description of a new genus Ptisana, 57(3): 737-755.

Nagalingum N.S., Nowak, M.D. and Pryer, K.M. 2008. Assessing phylogenetic relationships in extant heterosporous ferns (Salviniales), with a focus on Pilularia and Salvinia. Botanical J. Linnean Soc., 157: 673-685.

Pelton and Robert. 2011. The Official Pocket Edible Plant Survival Manual. 25.

Srivastava, K. 2007. Importance of Ferns in Human Medicine, 11: $231-234$.

Stace and Clive. 2010. New Flora of the British Isles. Cambridge, UK: Cambridge University Press. ISBN 9780-521-70772-5.

Taylor, T.N., Taylor E.L. and Krings, M. 2009. Paleobotany: The Biology and Evolution of Fossil Plants. New York: Academic Press.

Vanhemessen, W. 2013. The diversity of plant in Ontario.

Vasco, A., Barbara, R.M. and Ambrose, A. 2013. The evolution, morphology and development of ferns leave, 4: 345.

Vu, K. 2016. Common uses of ferns.

Wolf, P.G., Roper, J.M. and Duffy, A.M. 2010. The evolution of chloroplast genome structure in fern, 53(9): 731-8.

Wolf, P.G., Schneider, H. and Ranker, T.A. 2001. Geographic distribution of homosporous Ferns does dispersal obscure evidence of vicariance, 28: 263- 270.

\section{How to cite this article:}

Teena Agrawal, Priyanka Danai, Monika Yadav. 2017. General Aspects of Pteridophyta - A Review. Int.J.Curr.Res.Aca.Rev. 5(3), 80-85. doi: https://doi.org/10.20546/ijcrar.2017.503.012 